\title{
The Self-employment of Women in Azerbaijan
}

\begin{abstract}
Azerbaijan has a population of more than 10 million, of which women accounted for $50 \%$ in 2020 . At the same time, $93 \%$ of Azerbaijan's citizens describe themselves as Muslims. Since the beginning of independence, Azerbaijan has been a secular state by virtue of Article 48 of the Constitution, which guarantees the freedom of worship, choice, or nonpractice of religion and the freedom of expression of one's own views on religion. This article aims to assess the changes in the self-employment of women in Azerbaijan through a deductive analysis of data and observation of changes in the structure of resources based on generally available macroeconomic data. This study focuses on the situation of women on the Azerbaijani labour market over the two decades of the 21st century. The numbers of economically active women, including those in employment and the unemployed, and economically inactive women are specified. Further, the government's legal and financial policy in respect of women's self-employment is analysed. The author determines what percentage of companies were set up by women and in which sectors and locations.
\end{abstract}

Keywords: Azerbaijan, Women, Wages, Self-employment, State Aid

\section{Introduction}

The nature of small businesses in transition economies differs from that in developed market economies in that financial and market conditions in the latter are generally more stable and favourable to entrepreneurs and small businesses. ${ }^{1}$ Azerbaijan uses the profits from the sale of oil and

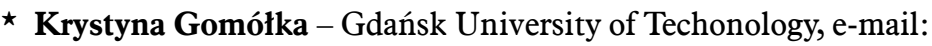
kgom@zie.pg.gda.pl, ORCID: 0000-0002-7046-0729.

1 S. Jung-Wan Lee, W. Tai, Motivators and inhibitors of entrepreneurship and small business development in Kazakhstan, "WJEMSD", no. 1-2(6)/2010, DOI: https://doi. org/10.1108/20425961201000006. 
gas to finance education, job creation, the development of services, and to promote women's self-employment.

The aim of this article is to estimate, through a deductive analysis of macroeconomic data, the number of self-employed women and the sectors and regions where they have established their businesses. These processes are evaluated against the background of demographic changes, by presenting and analysing statistical data. The research hypothesis is as follows: neither legislation nor state financial aid have contributed to the development of women's self-employment.

In order to verify this hypothesis, the author analysed women's situation on the labour market, the legal and financial assistance offered by the state, and made an attempt to assess the conditions for women's entrepreneurship and the number of businesses set up by women in different economic sectors. This study is based on official statistical data of Azerbaijan and literature on the subject in Russian and English.

There are not many publications about women's situation on the labour market in Azerbaijan. The issue of women's economic activity is usually addressed in the context of the changes in Azerbaijan's legislation. An article by Farida Akhudova examines the qualifications of Azerbaijani human capital. The author recommends amendments to the laws of Azerbaijan to increase the job security of employees by promoting indefinite-term employment contracts. ${ }^{2}$ The need to ensure foreign companies' compliance with the Labour Code and to hire Azerbaijan is pointed out by Elnur Aliyev. ${ }^{3}$ Aynura Piriyeva shows that improving the quality of human resources plays a key role in labour market development and improvement. According to the author, the labour market in Azerbaijan has three characteristic features: a) the existence of a skills gap; b) a large number of emigrants with university degrees; and c) university graduates taking up employment in companies that offer good salaries and training to help professional development. ${ }^{4}$

A 1990-2010 labour market analysis carried out by Ramiz Rahmanov, Asif Gasimov and Gulzar Tahirov demonstrates that the Azerbaijani labour market is characterised by a relatively high economic activity rate

2 F. Akhundova, Human Capital in Focus: Global and Local Trends, Labour Market in Azerbaijan, American Chamber Amcham Commerce in Azerbaijan, Baku 2013, http:// amcham.az/wp-content/uploads/2016/11/impact16.pdf (access 16.02.2021).

3 E. Aliyev, Commercial Courts as Part of Fudicial-Legal Reforms, American Chamber Amcham Commerce in Azerbaijan, Baku 2019, https://amcham.az/uploads/publicati on/19ca14e7ea6328a42e0eb13d585e4c22.pdf?v=1579164919 (access 3.12.2020).

4 A. Piriyeva, The US-educated Azerbaijan alumni association, "Context", no. 5/2013, https://aaa.org.az/wp-content/uploads/2017/07/Context\%20V\%20ENG.pdf (access 27.04.2021). 
of citizens and a low female unemployment rate. The undesirable features of the Azerbaijani labour market at the turn of the 20th and 21st century identified by the authors include: a growing number of poorly-educated workers and an excessive increase in labour costs unrelated to increased productivity. $^{5}$

A report by Azer Allahveranov and Emin Huseynov stressed that the government used the revenue from the sale of oil to support education and infrastructure development. These measures resulted in an increased secondary education completion rate, the creation of new jobs, the introduction of a statutory minimum wage and targeted social assistance which, according to the authors, reduced the poverty rates from $49 \%$ in 2001 to $9.1 \%$ in $2010 .^{6}$

The standard working week in Azerbaijan in 2020 was five eight-hour working days plus a two-day weekend. Employees were entitled to a 21day annual leave, with additional days off granted to young workers under 18 years of age, mothers, and those in hazardous occupations. The law prohibits overtime in the case of workers under 18 years of age, pregnant women, and mothers of children below the age of three. Although in 2019 more Azerbaijani women worked full-time compared to 2000, their share of family responsibilities had not decreased. Compared to 2000, at the end of the 2010s more children attended kindergartens, but the high costs of private childcare facilities effectively reduced their accessibility for many families. ${ }^{7}$ The gender pay gap did not change over the first two decades of the 21st century. Despite the same level of education, more women tended to take up employment in low-wage sectors. The proportion of women in managerial positions was around $10 \% .{ }^{8}$ When seeking firsttime employment after graduation, young women came up against major barriers. $^{9}$

${ }^{5}$ R. Rahmanov, A. Gasimov, G. Tahirova, The Labor market in Azerbaijan, "Working Paper Series”, no. 2/2016, https://uploads.cbar.az/assets/058cf3b4ee0d7861934a66 7d3.pdf (access 3.03.2021).

${ }^{6}$ A. Allahveranov, E. Huseynov, Costs and Benefits of Labour Mobility between the EU and the Eastern Partnership Partner Countries - Country Report: Azerbaijan, "Case Network Studies and Analyses”, no. 460/2013, https://papers.ssrn.com/sol3/papers. cfm?abstract_id $=2322655$ (access 3.12.2020).

${ }^{7}$ M. Basakova, Youth the Labour market of modern Azerbaijan: Gender Aspect, "Bulletin of the Institute of Economics of the Russian Academy of Sciences”, no. 2/2013.

${ }^{8}$ F. Akhundova, Human Capital in Focus: Global and Local Trends, Labour Market in Azerbaijan, American Chamber Amcham Commerce in Azerbaijan, Baku 2013, http:// amcham.az/wp-content/uploads/2016/11/impact16.pdf (access 16.02.2021).

9 M. Basakova, Young people in Azerbaijan: The gender aspect of transition from education to decent work, Working Paper No. 5, ILO Decent Work Technical Support Team and Country Office for Eastern Europe and Central Asia, Moscow 2012. 
An analysis of the labour market of the 2010s conducted by three Russian researchers shows that global challenges are leading to continuous changes in the labour market in Azerbaijan. Young citizens of Azerbaijan choose their profession according to the criterion of income. The authors suggest upgrading education programmes at universities and reducing youth training in the segments with an over-supply of workforce. ${ }^{10}$ Maarten Klaveren, Kea Tijdens, Melanie Wiliams, and Nuria Ramos Martin conducted a review of women's employment in Azerbaijan in the first decade of the 21 st century. The authors argue that the laws adopted by the parliament of Azerbaijan, aiming to ensure equal treatment for men and women in taking up employment, are not followed in practice and women are treated less favourably than men. They work in lower-paid jobs in the traditionally "female" sectors, i.e., education, health care, or general sector of services, and are often forced to quit their jobs for family reasons. They also often suffer domestic violence. ${ }^{11}$

Rena Ibragimbekova analyses the problems of women working in agricultural holdings in Azerbaijan. Professor Ibragimbekova recommends that the authorities should develop training programmes for female farmers and promote their entrepreneurship to help them work close to their homes and reconcile their work with their household responsibilities. ${ }^{12}$

An overall assessment of the gender policy in Azerbaijan was carried out by the Asian Development Bank in 2019. The resultant report is divided into several chapters which present national and international gender equality policies and their practical implementation. The report emphasises that the oil sector's profits allocated to schemes relating to women's education, improvement of maternal and infant health and better water supply have produced measurable effects. There has been an increase in the number of female university graduates taking up employment, and the number of doctors providing mother and child care has increased. An improved water supply to households has improved the living conditions of many families. Still, not enough women hold

${ }^{10}$ L.V. Kashirskaya, A. Sitnova, K.O. Shamasheva, Forecast of Labour Market Development in Azerbaijan, "Problems of Economics and Legal Practice", no. 6/2018.

11 M. Klaveren et al., An overview of women's work and employment in Azerbaijan, "Working Paper", 10-92, May 2010, University of Amsterdam, https://www.researchgate.net/publication/254390839_An_overview_of_women's_work_and_employment_in_Azerbaijan (access 20.02.202̄̄).

${ }_{12}^{-}$R. Ibragimbekova, Gender problems in agriculture in Azerbaijan, "International Agricultural Journal”, no. 5/2017, https://mshj.ru/wp-content/uploads/2017/09/ MSHJ-5_text_gotovo.pdf (access 20.02.2021). 
positions in local and central authorities, and there are gender-related pay differences and occupational segregation. ${ }^{13}$

Aysel Vazirova presents women's opinions about working in the public and private sectors. According to the author, most women choose to work in the public sector to enjoy the guaranteed working mothers' rights and fixed working hours. The study mentions good government practices intended to meet women's needs and stresses the importance of increased aid to promote women's entrepreneurship by building professional associations that provide the necessary expertise and skills for self-employment, and of the establishment of business incubators. The author has identified the following existing barriers to female entrepreneurship: marginalisation at work, gender-based discriminatory practices - especially in the private sector, women being passed over for promotion, workplace harassment, heavy household duties, limited mobility, and restricted access to credit and technologies. ${ }^{14}$

\section{Women on the Labour Market}

Between 2000 and 2019, the population of the Republic of Azerbaijan increased. In 2000, women accounted for $51.1 \%$, and in 2020 for $50.1 \%$ of the total population. The sex ratio varied between age groups. (Population in Azerbaijan, 2020). An increased percentage of women in older age groups was mainly due to a higher mortality rate of young men caused by biological, social, economic, and cultural factors associated with gender stereotypes wherein men should be active, strong, and independent whereas women should be passive and obedient. ${ }^{15}$ In 2020, women aged 15-19 accounted for $46.7 \%$, those aged $30-34$ for $50.6 \%$ and women between 65 and 69 for $54.9 \%$ of the total population. ${ }^{16}$

The Republic of Azerbaijan has a democratic and secular education system. The right to education is guaranteed by the Constitution (Article

${ }_{13}$ Azerbaijan Country Gender Assessment, December 2019, https://www.adb.org/ sites/default/files/institutional-document/546166/azerbaijan-country-gender-assessment-2019.pdf (access 12.12.2020).

14 A. Vazirowa, Women in the private sector in Azerbaijan. Opportunities and challenges, Gender Assesment Report, UNDP 2018, https://azerbaijan.unfpa.org/ sites/default/files/pub-pdf/UNDP-AZE-Gender-Assessmnet-kitab-eng_v4_view.pdf (access 12.03.2021).

15 M. Basakova, Young people in Azerbaijan: The gender aspect of transition from education to decent work, Working Paper No. 5, ILO Decent Work Technical Support Team and Country Office for Eastern Europe and Central Asia, Moscow 2012.

16 Demographics 2020, https://www.worldometers.info/demographics/azerbaijandemographics/ (access 20.12.2020). 
42) and by the Law on Education of the Republic of Azerbaijan. The State provides free compulsory secondary education and guarantees all Azerbaijan's citizens the right to education irrespective of nationality, religion, race, language, sex, age, state of health, social status, place of residence, or political views. ${ }^{17}$

Education helps to improve the competitiveness of women in the labour market and to achieve real gender equality in employment. An increase in the number of women completing secondary education could be observed in the late 2010s. However, women still represented a smaller percentage of the undergraduates in the academic year 2019/2020: $31.9 \%$ in humanities and social sciences, $19.6 \%$ in education, $15.3 \%$ in natural sciences, and $11.4 \%$ in economics and management (Education, science and culture 1999-2018). From year to year, the number of economically active women was increasing, and more and more women were taking up employment. Since the end of the 1990s, the working age criteria in Azerbaijan have been altered several times. Until 1999, it was 16-59 for men and 16-54 for women. In 2018 the working age range was changed to 15-63 for men and 15-60 for women. ${ }^{18}$ As a result of the extension of the working age range, the population able to take up employment has increased. The first two decades of the 21st century saw a decrease in the percentage of the unemployed and economically inactive. One of the reasons for the productive age range extension was an increase in the life expectancy of Azerbaijan's citizens. Compared to 2000, the life expectancy of women and men in 2019 was greater by 8.4 years for men and by 9.8 years for women. ${ }^{19}$ The fertility rate in 2020 was 2.08 births per woman. ${ }^{20}$

Article 25 of the Constitution of Azerbaijan guarantees equal rights for men and women, which includes equal pay for their work. ${ }^{21}$ Azerbaijan ratified the 1951 International Labour Organization (ILO) Convention

${ }_{17}$ Gender equality and gender relations in Azerbaijan current trends and opportunities, Findings from the Men and the Gender Equality Survey (IMAGES), Baku 2018, https://azerbaijan.unfpa.org/sites/default/files/pub-pdf/gender\%20equality-en.pdf (access 6.02.2021).

18 T. Bayranova, Effects of ongoing oil crisis into the Azerbaijan labour market. Unemployment challenges and its solution ways, Baku 2016; N. Verdijeva, How the population of the Republic of Azerbaijan is ageing: causes and potential for social and economic development, "Population and Economics", no. 3/2019, https://populationandeconomics. pensoft.net/article/47233/element/8/88382//(access 12.03.2021).

19 Life in Azerbaijan. 2020, https://www.google.com/publicdata/explore?ds=d5bnc ppjof8f9_\&met_y $=s p \_d y n \_l e 00 \_i n \& i d i m=$ country:AZE:ARM:GEO\&hl $=\mathrm{pl} \& \mathrm{dl}=\mathrm{pl}$ (access 1.03.2021).

${ }^{20}$ Ibidem.

${ }^{21}$ The Constitution of the Azerbaijan Republic, https://static.president.az/media/ W1siZiIsIjIwMTkvMTIv MDQvNjdvbm8wNTJ2bF9rb25zdHV0aXN5YV9ydXNf dXBkYXRlLnBkZiJdXQ?sha=6f0a333c8a816eee (access 10.03.2021). 
Table 1. Economically active and inactive working-age women in 2000 2020 (\%)

\begin{tabular}{|c|c|c|c|c|c|}
\hline Year & $\begin{array}{c}\text { Total } \\
\text { women } \\
(\%)\end{array}$ & $\begin{array}{c}\text { Economically } \\
\text { active` }\end{array}$ & Employed & $\begin{array}{c}\text { Unemployed } \\
(\%)\end{array}$ & $\begin{array}{c}\text { Economically } \\
\text { inactive }\end{array}$ \\
\hline 2000 & 100 & 56.26 & 43.49 & 12.77 & 43.74 \\
\hline 2001 & 100 & 56.49 & 44.49 & 11.54 & 43.51 \\
\hline 2002 & 100 & 56.73 & 44.95 & 10.37 & 43.27 \\
\hline 2003 & 100 & 57.00 & 44.76 & 9.24 & 43.00 \\
\hline 2004 & 100 & 57.30 & 49.25 & 8.05 & 42.70 \\
\hline 2005 & 100 & 57.66 & 50.31 & 7.35 & 42.34 \\
\hline 2006 & 100 & 58.05 & 51.72 & 6.33 & 41.95 \\
\hline 2007 & 100 & 58.52 & 53.26 & 5.26 & 41.48 \\
\hline 2008 & 100 & 59.04 & 54.11 & 4.93 & 40.96 \\
\hline 2009 & 100 & 59.62 & 53.03 & 6.59 & 40.38 \\
\hline 2010 & 100 & 60.22 & 53.29 & 6.93 & 39.88 \\
\hline 2011 & 100 & 60.81 & 54.36 & 6.45 & 39.19 \\
\hline 2012 & 100 & 61.10 & 55.01 & 6.09 & 38.90 \\
\hline 2013 & 100 & 61.32 & 55.37 & 5.95 & 38.86 \\
\hline 2014 & 100 & 61.92 & 56.08 & 5.84 & 38.08 \\
\hline 2015 & 100 & 62.52 & 56.65 & 5.87 & 37.48 \\
\hline 2016 & 100 & 62.98 & 57.07 & 5.91 & 37.02 \\
\hline 2017 & 100 & 63.30 & 57.37 & 5.93 & 36.70 \\
\hline 2018 & 100 & 63.66 & 57.89 & 5.77 & 36.34 \\
\hline 2019 & 100 & 63.41 & 57.07 & 6.34 & 36.59 \\
\hline 2020 & 100 & 63.13 & 56.37 & 6.76 & 36.87 \\
\hline
\end{tabular}

Source: own study based on: Female labour force participation, https://www.theglobaleconomy.com/Azerbaijan/Female_labor_force_participation (access 4.02.2021); Number of employed population, Economic activity of population, Number of unemployed population, https://www.stat.gov.az/source/labour/?lang=en (access 3.03.2021).

on equal pay (No 100) (Equal Remuneration Convention, 1951), the 1958 Convention on discrimination in employment and occupation (No 111) (Discrimination Employment and Occupation Convention, 1958), the 1983 Convention concerning equal treatment of men and women workers with family responsibilities (No 156) (Workers with Family Responsibilities Convention, 1981) and the UN Convention on the elimination of all forms of discrimination against women. ${ }^{22}$ Gender

${ }^{22}$ Convention on the Elimination of all Forms of Discrimination against Women, New York December 1979, https://www.ohchr.org/en/professionalinterest/ pages/ cedaw.aspx (access 11.01.2021). 
discrimination is also prohibited by the Azerbaijan Labour Code. ${ }^{23}$ Despite this, the remuneration of women taking up work was and is still lower than that of their male counterparts.

Table 2. Monthly salaries of women and men in 2019 in the individual sectors of the economy

\begin{tabular}{|l|r|r|r|}
\hline \multicolumn{1}{|c|}{ Sector of economy } & $\begin{array}{c}\text { Men's } \\
\text { salaries } \\
\text { (manat) }\end{array}$ & $\begin{array}{c}\text { Women's } \\
\text { salaries } \\
\text { (manat) }\end{array}$ & $\begin{array}{c}\text { Pay gap } \\
(\%)\end{array}$ \\
\hline Agriculture, forestry and fishing & 384.5 & 328.5 & $14.56 \%$ \\
\hline Mining & 3244.6 & 1812.0 & $44.15 \%$ \\
\hline Manufacturing & 706.6 & 417.4 & $40.93 \%$ \\
\hline $\begin{array}{l}\text { Electricity, gas and steam production, distri- } \\
\text { bution and supply }\end{array}$ & 654.3 & 514.0 & $21.44 \%$ \\
\hline Water supply, waste treatment and disposal & 525.0 & 364.0 & $30.67 \%$ \\
\hline Construction & 751.3 & 562.9 & $25.08 \%$ \\
\hline Trade; repair of transport means & 499.6 & 414.2 & $17.09 \%$ \\
\hline Transportation and storage & 909.6 & 585.7 & $35.61 \%$ \\
\hline Transportation and storage & 594.1 & 510.4 & $14.09 \%$ \\
\hline Information and communication & 1077.5 & 835.8 & $22.43 \%$ \\
\hline Financial and insurance activities & 1844.1 & 1160.6 & $37.06 \%$ \\
\hline Financial and insurance activities & 631.4 & 406.6 & $35.60 \%$ \\
\hline Professional, scientific and technical activities & 1582.7 & 687.2 & $56.58 \%$ \\
\hline Administrative and support service activities & 461.8 & 259.8 & $43.74 \%$ \\
\hline Administrative and support service activities & 850.4 & 666.9 & $21.58 \%$ \\
\hline Education & 521.0 & 409.7 & $21.36 \%$ \\
\hline Human health and social work activities & 449.2 & 325.1 & $27.63 \%$ \\
\hline Art, entertainment and recreation & 528.9 & 360.2 & $31.90 \%$ \\
\hline Other service activities & 701.1 & 498.5 & $28.90 \%$ \\
\hline
\end{tabular}

Source: Average monthly nominal wages of women and men by types of economic activity in 2019, https://www.stat.gov.az/source/gender/?lang=en (access 10.12.2020).

Employers in Azerbaijan do not adopt a single position on male and female employment. A study conducted in Azerbaijan has shown that the provisions of the labour law concerning women's employment are respected only by state-owned companies, public authorities, and large foreign companies, as opposed to private company owners who still remain under the influence of the traditional perception of gender

${ }^{23}$ Labour Code of the Republic of Azerbaijan (Adopted by the Law of Azerbaijan Republic of February 01, 1999, N 618-IG), http://ask.org.az/wp-content/uploads/2018/11/ Labour-Code-of-the-Republic-of-Azerbaijan.pdf (access 22.02.2021). 
roles in the Azerbaijani society. In the eyes of employers, it makes young women unreliable, "second-rate" employees and reduces the value of their work. With less territorial mobility compared to young men, young women living in villages and small towns face additional employment barriers. Furthermore, entrepreneurs consider men the main breadwinners responsible for the security and safety of their families, whereas women are seen as "housewives, protectors of the hearth and home, and mothers". ${ }^{24}$

\section{Public Policy Regarding Self-employment}

Despite the fact that the idea of gender equality has been around in Azerbaijan since the beginning of independence, it was only in 1998 when the State Committee on Women's Affairs was established. The Committee, along with selected women's NGOS, received technical assistance under the "Development of Gender in Azerbaijan" project. The Committee set up a coordination unit for female entrepreneurs, an Inter-ministerial Council consisting of representatives of ministries and women's NGOs. On 6 March 2000, the President signed a decree "On implementing state policy regarding women in the Republic of Azerbaijan". It guarantees women equality with men in representation in the national authorities. ${ }^{25}$

Azerbaijan does not have a single specific strategy for women's selfemployment, which is addressed in the following documents: the Programme on Socio-Economic Development of Regions (2014-2018), the Youth Programme (2011-2015), the Poverty Reduction Programme (2008-2015), the Food Safety Program (2008-2015), and the Development Concept "Azerbaijan 2020". The "National Action Plan for Women 20002005 " includes a chapter on "Women in the Economy", which provides for a number of measures to promote female entrepreneurship:

- the development of a program of long-term loans and micro-loans for women starting a business by state-owned and commercial banks and international organisations;

- the organisation of management and accounting courses for female entrepreneurs;

${ }^{24}$ M. Basakova, Young people in Azerbaijan: The gender aspect of transition from education to decent work, Working Paper No. 5, ILO Decent Work Technical Support Team and Country Office for Eastern Europe and Central Asia, Moscow 2012; Decent Work Country Profile Azerbaijan 2012, https://www.ilo.org/wcmsp5/groups/public/---europe/---rogeneva/---sromoscow/documents/publication/wcms_307259.pdf. (access 12.01.2021).

${ }_{25}$ Azerbaijan commits to mainstream gender in all State programmes and legislation to help working women (updated), https://www.unwomen.org/en/get-involved/step-it-up/ commitments/azerbaijan (access 10.12.2020). 
- promoting female entrepreneurship in rural areas taking into account the local conditions to reduce unemployment (carpet weaving, horticulture, the fishery and tobacco industries);

- engaging female entrepreneurs in the development of state programmes and self-employment strategies;

- encouraging international entities to assist national financial organisations in expanding their services for female entrepreneurs;

- helping female entrepreneurs to develop technical and business links at national, regional, and international levels;

- the establishment of the Centre For Legal Assistance to Female Entrepreneurs;

- the establishment of the Labour Market Information Centre and drawing on the experience of foreign female entrepreneurs;

- the establishment of the Female Entrepreneurs Association. ${ }^{26}$

In December 2016, the government of Azerbaijan adopted a "strategic roadmap for the production of consumer goods in Azerbaijan at the level of small and medium entrepreneurship". It was a breakthrough in the supply of services and the development of SMEs in Azerbaijan, which included provisions on support for companies set up by women. ${ }^{27}$ Assistance for SMEs and start-ups was to be provided by the newly-established SME Development Agency (SMBDA) with a share capital of EUR 2.5 million. However, until the end of 2019, government support to entrepreneurs remained limited for unknown reasons and its size is not known. ${ }^{28}$ Between 2006-2009, the government developed and implemented the first training programmes for unemployed women, and conducted pilot projects to promote women's selfemployment. ${ }^{29}$ Since 2015, educational and training projects have been in place to counteract violence against women and girls, protect health and increase the participation of women in the country's economic life. ${ }^{30}$

26 Country programme document for the Republic of Azerbaijan 2016-2020, https:// digitallibrary.un.org/record/814757 (access 11.01.2021).

${ }_{27}$ Azerbaijan. Country gender assessment, Asian Development Bank Manila, 2019 https://www.adb.org/sites/default/files/institutional-document/546166/azerbaijancountry-gender-assessment-2019.pdf (access 12.01.2021).

${ }_{28}$ Azerbaijan Small Business Act Country Profile, 2020, https://www.oecd-ilibrary. org/sites/42efdlf2en/index.html?itemId=/content/component/42efdlf2-en (access 21.12.2020).

${ }^{29}$ Guide for the formulation of the National Employment Policies, International Labour Organisation, 2013, https://www.ilo.org/emppolicy/pubs/WCMS_188048/lang--en/index.htm (access 16.02.2021).

${ }^{30}$ Azerbaijan commits to mainstream gender in all State programmes and legislation to help working women (updated), https:/www.unwomen.org/en/get-involved/step-it-up/ commitments/azerbaijan (access 10.12.2020). 
In 2018, the Entrepreneurship Development Fund was created in Azerbaijan, which succeeded the National Entrepreneurship Support Fund. The annual interest rate on low-interest loans granted by the Entrepreneurship Development Fund was reduced from 6\% to 5\%. ${ }^{31}$ In his decree, the President of Azerbaijan listed the areas in which the State would provide financial assistance to start-up businesses. These included: the sorting, packaging, and transport of agricultural products, the irrigation of fields (minimum area $50 \mathrm{ha}$ ), the growing of melons and tea, breeding beef and dairy cattle, fish farming, the manufacture of tobacco products, textiles, and leather products, timber processing and the manufacture of wood, paper, and cardboard products. In addition to the forestry and fishery sectors, financial support was to be provided to individuals setting up businesses manufacturing chemical and petrochemical products, pharmaceutical products, plastics, construction materials, metal and steel products, computers, electrical equipment, renewable energy systems, jewellery and medical instruments, as well as to companies building tourist facilities. ${ }^{32}$

In practice, the size and extent of the aid are not precisely known. Farmers and small agricultural companies can also benefit from assistance offered by the Agrarian Credit and Development Agency. Following a merger of the Azerbaijan Mortgage Fund and the Loan Guarantee Fund, the Mortgage and Credit Guarantee Fund of the Republic of Azerbaijan was established in 2017 to provide support to entrepreneurs. Non-bank, private finance institutions in Azerbaijan are not very well developed, and reliable statistics on these activities are not available which makes it impossible to offer a comprehensive assessment of financial assistance.

Support for female entrepreneurship has been included in the action plans of the Ministries of Economy, Labour, and Social Protection, Youth and Sport, as well as of business associations. The following actions are envisaged: sharing good practices among female entrepreneurs, developing loan mechanisms for women intending to start a business (especially in rural areas), setting up business incubators and providing self-employment advisory services for young women. Long-term schemes include the development of a female entrepreneurship plan, whereas in

${ }^{31}$ Entrepreneurship Development Fund of the Republic of Azerbaijan. About Fund, 2019, http://edf.gov.az/en/content/97 (access 1.12.2020).

${ }^{32}$ Decree of the president of the Republic of Azerbaijan on approval of economic areas for investments, minimum amount of the capacity of investment projects and administrative - territorial units of investments to be made 16 January 2016, http:// edf.gov.az/en/content/42 (access 11.03.2021). 
the short term, support is planned in the form of office equipment for NGOs promoting women's self-employment. ${ }^{33}$

In the programme titled "Azerbaijan 2020: Look into the Future", in the area of gender policy, it is recommended to take action to combat genderrelated violence, to ensure equal employment opportunities for women and men, to promote self-employment and improve the opportunities for women to obtain managerial positions. ${ }^{34}$

\section{Self-employment of Women in Practice}

According to literature on self-employment, there are two types of women who engage in business activity in Azerbaijan. The first group consists of wealthy and creative women seeking independence who want to be their own bosses. The second group start businesses because they are forced to work to support their families and have no other earning opportunities. The first type dominates in Baku and larger cities, and the second in smaller towns and villages. Women in cities are better educated and prepared to run their businesses than country women. In $88 \%$ of cases, the decision to start a business is taken by the woman herself. Research so far has shown that more than half of the companies set up by women will fail after one year due to a lack of financing. More than a third of self-employed women run their businesses at the company's premises, in shops or shopping centres. The vast majority of female-owned enterprises provide services to the local market (Gender equality and gender relations in Azerbaijan current trends and opportunities). More than $50 \%$ of female entrepreneurs are university graduates (with a bachelor's degree), the majority of whom are women aged $40-55$ years, with previous employment experience. More than $50 \%$ of women use their own savings when establishing a business because high interest rates prevent them from obtaining a bank loan for that purpose. ${ }^{35}$

According to the law of Azerbaijan, micro-enterprises are those with up to 10 employees and an estimated annual turnover of up to EUR 140,000 .

33 Share of Female Business Owners 2019, https://databank.worldbank.org/reports. aspx ? source $=283 \&$ series $=$ IC. WEF.LLCO.FE.ZS\# (access 10.03.2021).

34 Azerbaijan 2020: Look into the future, https://president.az/files/future_en.pdf (access 10.12.2020).

35 J. Alijeva, B. Zeynalova, Women entrepreneurship policy assessment and women entrepreneurs stakeholder survey, Baku 2016, https://psd-tvet.de/wp/wp-content/uploads/ AZ_GIZ-Women-Enrepreneurship.pdf (access 5.12.2020). 
Table 3. Enterprises in Azerbaijan

\begin{tabular}{|l|l|l|l|}
\hline & \multicolumn{1}{|c|}{ Micro } & \multicolumn{1}{c|}{ Small } & \multicolumn{1}{c|}{ Medium } \\
\hline $\begin{array}{l}\text { Number of em- } \\
\text { ployees }\end{array}$ & Up to 10 & Up to 50 & Up to 250 \\
\hline Trade turnover & $\begin{array}{l}\text { AZN 200,000 } \\
\text { EUR 140,000 }\end{array}$ & $\begin{array}{l}\text { AZN 3,000,000 } \\
\text { EUR 1,056,000 }\end{array}$ & $\begin{array}{l}\text { AZN 30,000,000 } \\
\text { EUR 15,690,000 }\end{array}$ \\
\hline
\end{tabular}

Source: Number of acting micro, small, and medium entrepreneurship subjects, https://www.stat.gov.az/source/entrepreneurship/?lang=en (access 1.03.2021).

According to data from the Ministry of Economy of Azerbaijan, 209,170 one-person enterprises were established in 2005, 243,473 in 2006, 182,286 in 2007, 186,491 in 2008, 186,765 in 2009, 192,596 in 2010 and 333,171 in 2011 . In that period, female-owned companies accounted for $8 \%$ of the total. ${ }^{36}$

As of 1 January 2020, women had set up 198,305 enterprises. ${ }^{37}$

Table 4. Enterprises set up by women and men as of 1 January 2020

\begin{tabular}{|l|r|r|r|r|}
\hline \multicolumn{1}{|c|}{ Economic activity } & $\begin{array}{c}\text { Enter- } \\
\text { prises } \\
\text { set up by } \\
\text { women }\end{array}$ & (\%) & $\begin{array}{c}\text { Enter- } \\
\text { prises } \\
\text { set up by } \\
\text { men }\end{array}$ & (\%) \\
\hline Agriculture, forestry and fishing & 62,524 & 31.5 & 176,728 & 24.7 \\
\hline Mining & 48 & 0.0 & 853 & 0.1 \\
\hline Manufacturing & 3,449 & 1.7 & 16,393 & 2.3 \\
\hline $\begin{array}{l}\text { Electricity, gas and steam produc- } \\
\text { tion, distribution and supply }\end{array}$ & 3 & 0.0 & 58 & 0.0 \\
\hline $\begin{array}{l}\text { Water supply; waste treatment and } \\
\text { disposal }\end{array}$ & 33 & 0.0 & 389 & 0.0 \\
\hline Construction & 624 & 0.3 & 14,176 & 2.0 \\
\hline Trade; repair of transport means & 45,852 & 23.1 & 175,632 & 24.5 \\
\hline Transportation and storage & 1,601 & 0.8 & 96,880 & 13.5 \\
\hline $\begin{array}{l}\text { Accommodation and food service } \\
\text { activities }\end{array}$ & 6,350 & 3.2 & 35,733 & 5.0 \\
\hline Information and communication & 1,498 & 0.8 & 6,588 & 0.9 \\
\hline Financial and insurance activities & 574 & 0.3 & 1,943 & 0.3 \\
\hline
\end{tabular}

36 Small and Medium Entrepreneurship in Azerbaijan, Country Assessment, 2020, http://cesd.az/new/wp-content/uploads/2011/05/CESD_Report-SMEs_Azerbaijan. $\operatorname{pdf}$ (access 10.03.2021).

${ }_{37}$ Number of private entrepreneurs by gender distribution and types of activity, as of 1 fanuary 2020, https://www.stat.gov.az/source/gender/?lang=en (access 1.03.2021). 


\begin{tabular}{|l|r|r|r|c|}
\hline Real estate activities & 4,107 & 2.1 & 10,559 & 1.5 \\
\hline $\begin{array}{l}\text { Professional, scientific and techni- } \\
\text { cal activities }\end{array}$ & 6,853 & 3.5 & 13,080 & 1.8 \\
\hline $\begin{array}{l}\text { Administrative and support service } \\
\text { activities }\end{array}$ & 3695 & 1.9 & 8020 & 1.1 \\
\hline Education & 5,175 & 2.6 & 2,883 & 0.4 \\
\hline $\begin{array}{l}\text { Human health and social work ac- } \\
\text { tivities }\end{array}$ & 1,366 & 0.7 & 1,995 & 0.3 \\
\hline Art, entertainment and recreation & 1,638 & 0.8 & 11,584 & 1.6 \\
\hline Other service activities & 44,332 & 22.4 & 112,302 & 15.7 \\
\hline $\begin{array}{l}\text { Activity of households; activity } \\
\text { regarding to commodities and } \\
\text { services produced by households } \\
\text { for private consumption }\end{array}$ & 8,583 & 4.3 & 30,520 & 4.3 \\
\hline Total & 198,305 & 100.0 & 716,316 & 100.0 \\
\hline
\end{tabular}

Source: Number of private entrepreneurs by gender distribution and types of activity, as of 1 January 2020, https://www.stat.gov.az/source/gender/?lang=en (access 1.03. 2021).

As of 1 January 2020, enterprises established by women accounted for $35.37 \%$ of the total number of companies in Azerbaijan. In 2019, the largest proportion of female-owned enterprises were set up in the sectors of agriculture, forestry and fishery, as well as trade and services (female labour force participation). In 2011, women tended to establish their businesses in the same sectors. ${ }^{38}$ The proportion of women among the self-employed was over $50 \%$, while only $39.4 \%$ of women were employers. ${ }^{39}$ This is a significant step forward compared to 2004, when just $3 \%$ of women were running their own businesses. ${ }^{40}$ The number of companies set up by women grew after 2010, which attracted government interest in that issue. In 2014, women's companies accounted for 12.2\%, and in 2015 for $15.1 \%$ of all established companies. ${ }^{41}$

38 J. Alijeva, B. Zeynalova, Women entrepreneurship policy assessment and women entrepreneurs stakeholder survey, Baku 2016, https://psd-tvet.de/wp/wp-content/uploads/ AZ_GIZ-Women-Enrepreneurship.pdf (access 5.12.2020).

${ }^{39}$ Ibidem.

$40 \mathrm{~J}$. Hilalova, Changes in the gender relations after the fall of the soviet Union: the case Azerbaijan, Lund 2014, https://lup.lub.lu.se/luur/download?func= downloadFile\&re cordOId $=4462881 \&$ fileOId $=4463631$ (access 16.02.2021).

${ }^{41}$ Share of Female Business Owners 2019, https://databank.worldbank.org/reports. aspx ? source $=283 \&$ series $=$ IC. WEF.LLCO.FE.ZS\# (access 10.03.2021). 
Table 5. Companies run by women and men in the regions of Azerbaijan as of 1 January 2020

\begin{tabular}{|l|c|c|c|c|}
\hline \multicolumn{1}{|c|}{ Region } & $\begin{array}{c}\text { Women } \\
\text { (thousand) }\end{array}$ & $\begin{array}{c}\text { Women } \\
\text { (\%) }\end{array}$ & $\begin{array}{c}\text { Men } \\
\text { (thousand) }\end{array}$ & Men (\%) \\
\hline Total Azerbaijan & 198,305 & 100 & 716,316 & 100,0 \\
\hline Baku city & 65,654 & 33.1 & 213,665 & 29.8 \\
\hline Absheron & 10,313 & 5.2 & 39,847 & 5.6 \\
\hline Ganja-Gazakh & 31,539 & 15.9 & 91,480 & 12.8 \\
\hline Shaki-Zagatala & 11,687 & 5.9 & 43,027 & 6.0 \\
\hline Lankaran & 19,468 & 9.8 & 67,814 & 9.5 \\
\hline Guba-Khachmaz & 10,817 & 5.5 & 41,989 & 5.8 \\
\hline Aran & 33,973 & 17.1 & 152,365 & 21.3 \\
\hline Yukhari Karabakh & 3,739 & 1.9 & 17,822 & 2.5 \\
\hline Kalbajar-Lachin & 545 & 0.3 & 2,090 & 0.3 \\
\hline Dakhlik Shirvan & 4,378 & 2.2 & 23,123 & 3.2 \\
\hline Nakhchivan Autonomous & 6,171 & 3.1 & 23,104 & 3.2 \\
\hline
\end{tabular}

Source: Number of private entrepreneurs by gender distribution, towns and regions of Republic of Azerbaijan, as of 1 January 2020, https:/www.stat.gov.az/source/ gender/?lang $=$ en $($ access 1.03.2021).

As of 1 January 2020, the largest percentage of women were working in Baku, followed by the provinces of Aran and Ganja-Gazakh. It was in these centres that the largest number of companies were established; $50.7 \%$ of enterprises were registered in Baku, $10.6 \%$ in Aran, $7.8 \%$ in Absheron, 7.1\% in Lankan, and the remainder in other regions.

Private companies were employing far more men than women, who accounted for $27.68 \%$ of the total number of workers. This was due to the reluctance of entrepreneurs to employ women, who are treated as second-rate workers and seen as responsible for looking after the family and home.

\section{Conclusions}

In $2020,50.1 \%$ of the population of Azerbaijan were female. Because of the availability of a free state education, an increasing proportion of the population, including women, completed secondary education. In the two decades of the 21 st century, the number of university students increased by $30 \%$. Young women were a minority among students, showing a preference for the humanities and social sciences. From year to year, the number of economically active women was increasing, and more and more women were taking up employment. Although equal pay 
regardless of gender is guaranteed by international conventions signed by Azerbaijan, the Constitution, and the Law on equal treatment, in practice the remuneration of women is much lower than that of their male counterparts. As of 2020, Azerbaijan had no single strategy for women's self-employment, but instead the issue was addressed in a number of documents prepared in 2005-2020: the National Action Plan for Women's Safety, the Programme on Socio-Economic Development of Regions, the Youth Programme, the Poverty Reduction Programme, the Food Safety Programme, and the Development Concept "Azerbaijan 2020". Of considerable importance for women's self-employment is the "Strategic Road Map for the production of consumer goods in Azerbaijan at the level of small and medium entrepreneurship", which envisaged assistance for SMEs and start-ups, including loans on preferential terms for future female entrepreneurs. However, it is impossible to determine the amount of funding granted by the Enterprise Development Fund until early 2020 due to a lack of data.

In scientific literature, two types of female-entrepreneurs are identified: the first being the wealthy and creative and the second being unemployed women who need to support their families. In the latter case, self-employed women used their own funds or loans from the family, as loans offered by banks were unattainable due to high interest rates. In Azerbaijan, the number of self-employed women and female entrepreneurs grew gradually; in 2004, women set up 3\% of businesses, compared to $35.37 \%$ in 2020. The employment structure in Azerbaijan in 2020 at the end of the 2010s was not highly evolved, with almost one third of the workforce still employed in agriculture which is the sector where the largest proportion of self-employed women set up their businesses. Other sectors with a large number of female-run enterprises were retail, estate agencies, and housing rental agencies. The main barriers to women's self-employment included the lack of capital, limited access to micro and macro-loans, and insufficient knowledge on how to run a business. A major obstacle to the establishment of one's own business was that female entrepreneurs were seen by some social groups as an extraordinary, unusual phenomenon. Furthermore, women were discouraged from self-employment by heavy family responsibilities, reduced mobility, and lower elasticity of the labour supply curve. In order to promote the self-employment of women, the government of Azerbaijan should help to increase the availability of micro-loans to enable women to operate their businesses in rural and urban areas, effectively promote self-employment among women, create "working from home" opportunities for women with no previous work experience and provide them with legal knowledge. It is also necessary to 
change the views held by conservative social groups and to have female entrepreneurs perceived as equal partners in business in those groups' eyes.

\section{References}

Aliyev E., Commercial Courts as Part of Fudicial-Legal Reforms, American Chamber Amcham Commerce in Azerbaijan, Baku 2019, https:// amcham.az/uploads/publication/19ca14e7ea6328a42e0eb13d585e4c22. pdf? $=1579164919$ (access 3.12.2020).

Akhundova F., Human Capital in Focus: Global and Local Trends, Labour Market in Azerbaijan, American Chamber Amcham Commerce in Azerbaijan, Baku 2013, http://amcham.az/wp-content/uploads/2016/11/impact16. pdf (access 16.02.2021).

Allahveranov A., Huseynov E., Costs and Benefits of Labour Mobility between the EU and the Eastern Partnership Partner Countries - Country Report: Azerbaijan, "Case Network Studies and Analyses", no. 460/2013, https://papers.ssrn.com/sol3/papers.cfm?abstract_id=2322655 (access 3.12.2020).

Alijeva J., Zeynalova B., Women entrepreneurship policy assessment and women entrepreneurs stakeholder survey, German Cooperation, Baku 2016, https://psd-tvet.de/wp/wp-content/uploads/AZ_GIZ-WomenEnrepreneurship.pdf (access 5.12.2020).

Average monthly nominal wages of women and men by types of economic activity in 2019, https://www.stat.gov.az/source/gender/?lang=en (access 10.12.2020).

Azerbaijan. Country gender assessment, Asian Development Bank Manila, 2019 https://www.adb.org/sites/default/files/institutional-document/ 546166/ azerbaijan-country-gender-assessment-2019.pdf (access 12.01.2021)

Azerbaijan 2020: Look into the future, https://president.az/files/future en.pdf (access 10.12.2020).

Azerbaijan commits to mainstream gender in all State programmes and legislation to help working women (updated), https://www.unwomen.org/en/getinvolved/step-it-up/commitments/azerbaijan (access 10.12.2020).

Azerbaijan Country Gender Assessment, December 2019, https://www.adb. org/documents/azerbaijan-country-gender-assessment-2019 (access 12.12.2020).

Azerbaijan Demographics 2020, https://www.worldometers.info/demographics/ azerbaijan-demographics/ (access 20.12.2020).

Azerbaijan Female labour force participation, https://www.theglobaleconomy. com/Azerbaijan/Female_labor_force_participation/(access 4.02.2021). 
Azerbaijan Small Business Act Country Profile, 2020, https://www. oecd-ilibrary.org/sites/42efd1f2-en/index.html?itemId=/content/ component/42efd1f2-en (access 21.12.2020).

Basakova M., Young people in Azerbaijan: The gender aspect of transition from education to decent work, Working Paper No. 5, ILO Decent Work Technical Support Team and Country Office for Eastern Europe and Central Asia, Moscow 2012.

Basakova M., Youth the Labour market of modern Azerbaijan: Gender Aspect, "Bulletin of the Institute of Economics of the Russian Academy of Sciences", no. 2/2013.

Bayranova T., Effects of ongoing oil crisis into the Azerbaijan labour market. Unemployment challenges and its solution ways, Baku 2016.

Convention on the Elimination of all forms of discrimination against women, New York December 1979, https://www.ohchr.org/en/ professionalinterest/pages/cedaw.aspx (access 11.01.2021).

Country programme document for the Republic of Azerbaijan 2016-2020, https://digitallibrary.un.org/record/814757 (access 11.01.2021).

Decree of the president of the Republic of Azerbaijan On Approval of economic areas for investments, minimum amount of the capacity of investment projects and administrative - territorial units of investments to be made 16 January 2016, https://www.dentons.com/en/ insights/alerts/2016/january/21/new-rules-on-investment-promotionin-azerbaijan (access 11.03.2021).

Decent Work Country Profile Azerbaijan 2012, https:/www.ilo.org/wcmsp5/ groups/public/---europe/---ro-geneva/---sro-moscow/documents/ publication/wcms_307259.pdf (access 12.01.2021).

Discrimination (Employment and Occupation) Convention, no. 111/1958, https://www.ilo.org/dyn/normlex/en/f?p=NORMLEXPUB:12100:0:: NO::P12100_ILO_CODE:C111 (access 18.012021).

Education, science and culture 1999-2018, https://www.stat.gov.az/source/ education/?lang $=$ en $($ access 22.01.2021).

Entrepreneurship Development Found of the Republic of Azerbaijan. About Fund, 2019, http://edf.gov.az/en/content/97 (access 1.12.2020).

Equal Remuneration Convention, no. 100/1951, https://www.ilo.org/ wcmsp5/groups/public/---ed_norm/---declaration/documents/ publication/wcms_decl_fs_84_en.pdf (access 2.01.2021).

Gender equality and gender relations in Azerbaijan current trends and opportunities, Findings from the Men and the Gender Equality Survey (IMAGES), United Nations Population Fund (UNFPA), Baku 2018, https://promundoglobal.org/wp-content/uploads/2018/12/IMAGESAzerbaijan-report-dragged.pdf (access 6.02.2021). 
Guide for the formulation of the National Employment Policies, International Labour Organisation, 2013, https://www.ilo.org/emppolicy/pubs/ WCMS_188048/lang--en/index.htm (acces 16.02.2021).

Hilalova J., Changes in the gender relations after the fall of the soviet Union: the case Azerbaijan, Department of Sociology, Bachelor of Science in Development, Lund 2014, https://lup.lub.lu.se/luur/download?func $=$ downloadFile $\&$ recordOId $=4462881 \&$ fileOId $=4463631$ (access 16.02.2021).

Ibragimbekova R.,GenderproblemsinagricultureinAzerbaijan, "International Agricultural Journal”, no. 5/2017, https://mshj.ru/wp-content/uploads/ 2017/09/MSHJ-5_text_gotovo.pdf (access 20.02.2021).

Jung-Wan Lee S., Tai W., Motivators and inhibitors of entrepreneurship and small business development in Kazakhstan, "WJEMSD”, no. 1-2(6)/2010, DOI: https://doi.org/10.1108/20425961201000006.

Klaveren M., et al., An overview of women's work and employment in Azerbaijan, "Decisions for Life MDG3 Project Country Report no. 9 - Working Paper”, no. 10-92, May 2010, https://www.researchgate. net/publication/239843659_An_overview_of_women's_work_and employment_in_Azerbaijan (access 20.02.2021).

Kashirskaya L.V., Sitnova A., Shamasheva K.O., Forecast of Labour Market Development in Azerbaijan, "Problems of Economics and Legal Practice", no. 6/2018.

Labor Code of the Republic of Azerbaijan (Adopted by the Law of Azerbaijan Republic of February 01, 1999, N 618-IG), http://ask.org.az/wp-content/ uploads/2018/11/Labour-Code-of-the-Republic-of-Azerbaijan.pdf (access 22.02.2021).

Life in Azerbaijan. 2020, https://www.google.com/publicdata/explore?ds $=\mathrm{d} 5 \mathrm{bncppjof8f9} \& \mathrm{met} \mathrm{y}=\mathrm{sp} \_\mathrm{dyn} \_l \mathrm{e} 00 \_$in $\& \mathrm{idim}=$ country:AZE:AR $\mathrm{M}: \mathrm{GEO} \& \mathrm{hl}=\mathrm{pl} \& \mathrm{dl}=\mathrm{pl}($ access $1.03 .202 \overline{1})$.

Number of acting micro, small and medium entrepreneurship subjects, https:// www.stat.gov.az/source/entrepreneurship/?lang=en (access 1.03.2021). Number of private entrepreneurs by gender distribution and types of activity, as of 1 Fanuary 2020, https://www.stat.gov.az/source/entrepreneurship /?lang = en (access 1.03.2021).

Number of private entrepreneurs by gender distribution, towns and regions of Republic of Azerbaijan, as of 1 January 2020, https://www.stat.gov.az/ source/gender/?lang = en (access 1.03.2021).

Number of employed population, Economic activity of population, Number of unemployed population, https://www.stat.gov.az/source/labour/?lang=en (access 3.03.2021).

Piriyeva A., The US-educated Azerbaijan alumni association, "Context", 
5/2013, https://aaa.org.az/wp-content/uploads/2017/07/Context $\% 20$ V\%20ENG.pdf (access 27.04.2021).

Population in Azerbaijan 2020, https:/www.worldometers.info/worldpopulation/azerbaijan-population/ (access 3.03.2021).

Rahmanov R., Gasimov A., Tahirova G., The Labor market in Azerbaijan, "Working Paper Series", no. 2/2016, https://uploads.cbar.az/assets/ 058 cf3b4ee0d7861934a667d3.pdf (access 3.03.2021).

Small and Medium Entrepreneurship in Azerbaijan, Country Assessment, 2020, http://cesd.az/new/wp-content/uploads/2011/05/CESD_ReportSMEs_Azerbaijan.pdf (access 10.03.2021).

Share of Female Business Owners, 2019, https://s1.q4cdn.com/692158879/ files/doc_library/file/2019-state-of-women-owned-businesses-report. pdf (access 10.03.2021).

The Constitution of the Azerbaijan Republic, The Constitution of the Azerbaijan Republic, https://static.president.az/media/W1si ZiIsIjIwMTkvMTIvMDQvNjdvbm8wNTJ2bF9rb25zdHV0aXN 5 YV9ydXNfdXBkYXRlLnBkZiJdXQ?sha $=6 f 0 a 333 c 8 a 816 e e$ (access 10.03.2021).

Tomorrow Azerbaijan will report to the UN Committee on the Elimination of All Forms of Discrimination against Women, https://www.ohchr. org/en/hrbodies/cedaw/pages/cedawindex.aspx (access 11.03.2021).

Vazirowa A., Women in private sector in Azerbaijan. Opportunities and challenges, Gender Assesment Report. UNDP 2018, https://www. az.undp.org/content/azerbaijan/en/home/library/UNDP-AZEGender-Assessment-report.html (access 12.03.2021).

Verdiyeva N., How the population of the Republic of Azerbaijan is ageing: causes and potential for social and economic development, "Population and Economics", no. 3/2019, https://populationandeconomics.pensoft.net/ article/47233/element/8/88382// (access 12.03.2021).

Workers with Family Responsibilities Convention (no. 156) 1981, https:// www.ilo.org/dyn/normlex/en/f?p = NORMLEXPUB:12100:0::NO::P 12100_ILO_CODE:C156 (access 10.03.2021). 